University of Rhode Island

DigitalCommons@URI

The Rhode Island Current Conditions Index

Economics

2-2009

\title{
Rhode Island Current Conditions Index - February 2009
}

Leonard Lardaro

University of Rhode Island, lardaro@uri.edu

Follow this and additional works at: https://digitalcommons.uri.edu/ricci

Part of the Econometrics Commons

Terms of Use

All rights reserved under copyright.

\section{Recommended Citation}

Lardaro, Leonard, "Rhode Island Current Conditions Index - February 2009" (2009). The Rhode Island Current Conditions Index. Paper 39.

https://digitalcommons.uri.edu/ricci/39

This Article is brought to you for free and open access by the Economics at DigitalCommons@URI. It has been accepted for inclusion in The Rhode Island Current Conditions Index by an authorized administrator of DigitalCommons@URI.For more information, please contact digitalcommons-group@uri.edu. 


\section{GURRENT

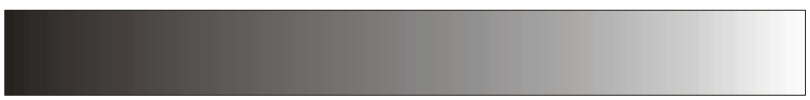

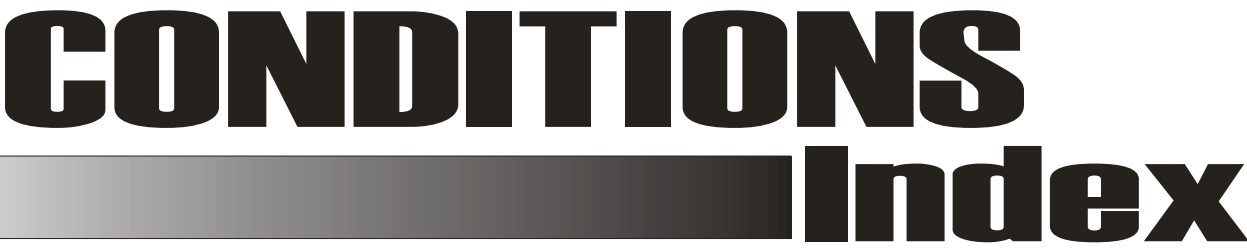

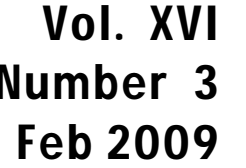

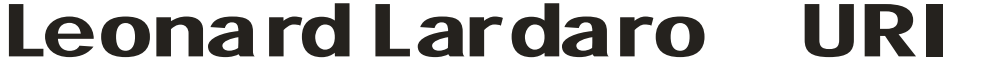

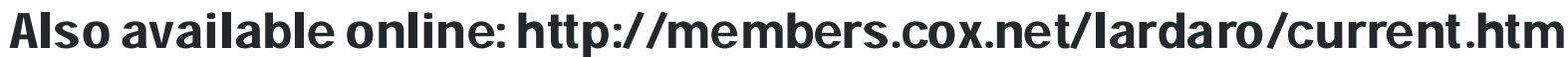

As Rhode Island continues to move past the disastrous fourth quarter of 2008, its economy continues to show signs of life. The Current Conditions Index for January was 17, the highest it had been since the end of 2007. For February, even though the $\mathrm{CCl}$ fell back to its all-too-familiar value of 8 , as only the Manufacturing Wage improved, there was more strength to February's economic performance than its $\mathrm{CCl}$ value indicates.

To place this into context, let me restate two points I have discussed several times over the past few years. First, not all $\mathrm{CCl}$ values of 8 are alike. Rhode Island's economic performance during the final two months of last year, both of which had $\mathrm{CCl}$ values of 8, was simply awful. Like the nation, Rhode Island seemed to fall off a cliff. So, consider those months "ugly" 8's compared to the $\mathrm{CCl}$ values of 8 earlier in 2008. Second, while rates of growth can at times become unsustainable, rates of decline can also be unsustainable. This is what both Rhode Island and the nation witnessed at the end of 2008. So, the process of recovery begins when we start to consistently match or exceed each prior month's economic performance. And as month-to-month, or sequential

\begin{tabular}{|lr|}
\hline \multicolumn{2}{|c|}{ CCI Indicators - \% Change } \\
Government Employment & -2.2 \\
US Consumer Sentiment & -20.3 \\
Single-Unit Permits & -70.3 \\
Retail Sales & -3.9 \\
Employment Services J obs & -20.5 \\
Priv. Serv-Prod Employment & -2.9 \\
Total Manufacturing Hours & -12.4 \\
Manufacturing Wage & 1.6 Y \\
Labor Force & -0.4 \\
Benefit Exhaustions & 54.4 \\
New Claims & 65.3 \\
Unemployment Rate & 61.5 \\
\hline \multicolumn{2}{|c|}{ Y = I mproved Value } \\
\hline
\end{tabular}

performance improves, the stage is set for improvement on a year-over-year basis. I believe Rhode Island is currently at this point, although one has to really dig into the data to be able to discern this.

Applying this last point to Rhode Island, even though only one indicator improved, giving a February $\mathrm{CCl}$ value of 8 , six of the twelve $\mathrm{CCl}$ indicators either improved or didn't deteriorate much in February. More importantly, two of those are leading indicators. So, if this pattern continues, and there is reason to believe it will if my conjecture that the fourth quarter was the most rapid rate of decline Rhode Island will witness, $\mathrm{CCl}$ values should begin to consistently improve as this year progresses. That doesn't mean that Rhode Island will definitely move into recovery this year, but we should move ever closer as this year progresses. Part of the reason for this is statistical: individual indicator performances during the fourth quarter of 2008 were so horrible, it will be almost impossible not to exceed many of them.

So, with all of this in mind, individual indicator performances, which compare to February of 2008, are still very bad. Single Unit Permits fell to 16 units statewide. While new home construction here has been virtually non-existent this year, this helps us draw down our inventory of unsold homes. Benefit Exhaustions, a measure of long-term unemployment jumped 54.4 percent, while New Claims, reflective of layoffs, sky rocketed 65.3 percent higher (partly related to phone backlogs). Along with this, our state's Unemployment Rate jumped to 10.5 percent, giving us a nation rank of fifth, as we saw a further decline in our Labor Force.

Total Manufacturing Hours plunged by 12.4 percent, the result of sharp declines in both employment and the workweek. Employment Service Jobs, a leading labor market indicator, dropped by 20.5 percent, although it improved relative to its value last month. Private ServiceProducing Employment fell by almost 3 percent, and Government Employment was 2.2 percent lower. Retail Sales fell by 3.9 percent, while US Consumer Sentiment also dropped sharply (by $20.3 \%$ ), it was only slightly lower than its value from last month.

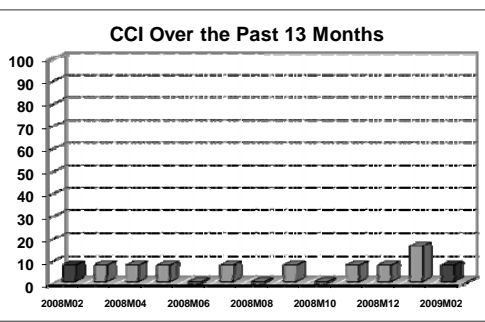

\section{THE BOTTOM LINE}

Happy days aren't here again, but we have clearly moved past the abyss at the end of last year. While Rhode Island's overall economic performance continues to be disappointing, signs of future strength are beginning to emerge based on monthly changes in a number of $\mathrm{CCl}$ indicators. If I am correct, we have moved beyond the most rapid rate of decline we will experience, so things should start to improve as this year progresses.

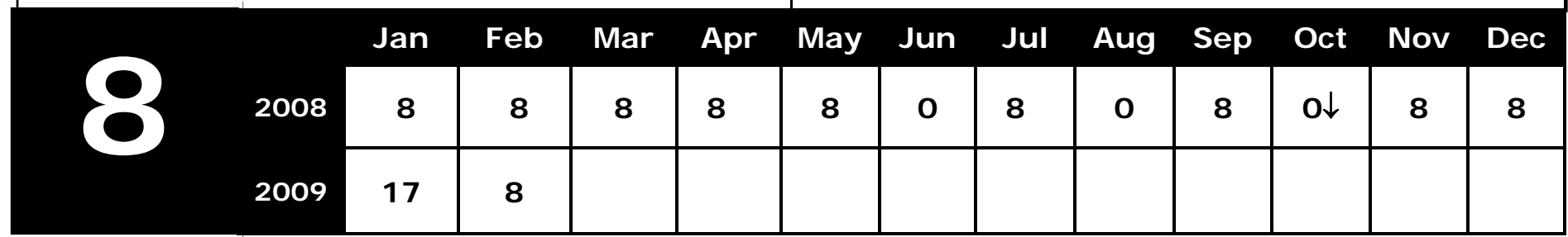

